\title{
Chapter 3 \\ The Changing Paths in Academic Careers in European Universities: Minor Steps and Major Milestones
}

\author{
Marek Kwiek and Dominik Antonowicz
}

\subsection{The Increasing Competition in the Academic Labor Market}

The academic career in Europe used to be much more unstructured and much less competitive than today. Currently, as reflected in interviews carried out throughout Europe, "each step in a career is competitive" (CH_18-MAN), from doctoral and postdoctoral to junior academic and senior academic positions. There are significant variations across the European countries studied regarding the level of competition, often different in different places occupied in the academic hierarchy. But increasing competition has come to the academic profession and is bound to stay: the competition for part-time and full-time academic positions, for research grants and research funding, and tokens of academic prestige.

The academic progression today has to be made systematically, in increasingly clearly defined timeframes, and the academic career seems to be sliced into comparable time periods across European systems. Usually, the timeframes are doctoral studies, employment in postdoctoral and junior positions, employment in lower-level senior positions and, finally, in higher-level senior positions (such as traditional chair holding and/or full professorships), and all career steps have to be reached within a certain time period. The competition in academic settings means

We gratefully acknowledge the support of the National Research Council (NCN) through grant DEC-2011/02/A/HS6/00183.

M. Kwiek $(\bowtie)$

Center for Public Policy Studies and UNESCO Chair in Institutional Research and Higher Education Policy, University of Poznan, ul. Szamarzewskiego 89, Poznan 60-569, Poland e-mail: kwiekm@amu.edu.pl

D. Antonowicz

Nicolaus Copernicus University, Torún, Poland 
most often measurable research outputs expected from academics for particular time periods or for particular stages of the academic career. Expectations from academics in the same stages of their careers are becoming largely similar throughout Europe. There seem to emerge an interesting combination of career progression requirements linked to age and/or specific time frames in academic careers. Increasing competition in all stages of careers is reported, and the competition is related to both employment (securing a post in the system; or retaining a post in the system; or progression up the academic ladder in the system) and securing research funding. The link between research funding and employment is viewed as strong as never before. In many cases, external funding generation actually means employment, especially for younger academics. A growing number of positions in universities are fixed-term, externally funded and project-based, especially at doctoral and postdoctoral levels. Under conditions of financial stringency felt in many European systems, the "market for academics" (Musselin 2010), the "academic labour market" (Williams et al. 1974), and especially the market for young doctoral graduates, becomes increasingly a "winner-take-all market", in particular in top research universities (Hacker and Pierson 2010; Frank and Cook 1995; Frank 1985; Brown et al. 2011). In such markets, often marginal differences in performance make the winners secure a position in the academic system, and make their marginally lower-performing competitors lose the battle for entering the higher education system. In previously, historically ever-expanding systems the competition to enter the higher education system was traditionally fierce but less of the "winner-take-all" character; with fewer new academic positions in academia today, and with systems often "frozen" due to the financial crisis, marginal differences in research performance of prospective entrants and new entrants to the system may count more than ever before, just as social networking abilities may count more. Where small differences matter, "luck", "chance", "accident" and "opportunity", historically important in academic careers, are becoming even more important.

The interviews with academics clearly show that the role of academic mentors (or academic patrons) has not been diminishing in the last few decades: the earlystage progression in the academic hierarchy is strongly linked to measurable research output and promising research achievements; but it is also linked to academic patronage: the academic progression "has to be based on scientific output, on scientific papers. But also academic networks among peers are important. A good environment for research is needed, however output is the most important criteria" (CH18_MAN). Academic mentors and academic mentorship play a powerful role in the early stages of the academic career, especially in the period of doctoral studies, the completion of which, currently, in most European systems, opens the possibility of entering the academic profession. A young academic must have a mentor "who would support him in networking and building social capital in/his research field. Good and supportive mentor is priceless" (PL27_AC). 


\subsection{Academic Mentors and Early Stages of the Academic Career}

The first milestone in the academic career is a decision to stay in the university sector, following, in most European systems, doctoral studies. Many junior academics interviewed explained that their decision to enter doctoral studies was linked to meeting an intellectual leader. There are several channels to formalize research activities under the formal umbrella of higher education institutions which create opportunities to enter the academic profession. Among them, the most popular - since the introduction of the Bologna framework of higher education is conducting research within doctoral study programs. The number of programs and the number of doctoral students have been on the rise in the last decade, though; in many European countries, enrollments in doctoral programs are currently reaching their historical records.

Not surprisingly, there is a feeling of increased competition among prospective academics. While the pool of doctoral students has been growing substantially, the number of academic posts available has not been keeping up with the pace of increase. Even though some programs are specifically designed to produce graduates for the business sector, in most cases in traditional universities doctoral students are inclined to consider the academic career as an important option. While the academic profession in most countries shows stagnating numbers, the pool of potential candidates seems ever-growing due to the expansion of doctoral studies. Consequently, in massified systems of doctoral education, only selected doctorate holders have a chance to ever enter the academic profession. The logic behind the expansion of doctoral education in both Europe and in the US is that "far more trained researchers than before will seek and will have to seek jobs outside academia and research institutions" (Kehm 2009, p. 155). Traditional forms of doctoral education and training do not seem to fit new government policy expectations across Europe. Consequently, based on a simple model of supply and demand, the competition for academic appointments has been growing as the number of posts available for doctoral holders outside of the university sector has also been falling behind the numbers of new doctorate holders. Part-time, projectbased, externally funded and fixed term appointments seem to be entering the European academic labor market arena for young doctoral holders to a much higher degree than ever before (in a way similar to, although still at a much lower scale than in the United States, see Schuster and Finkelstein 2006; Schuster 2011, as well as Kezar and Sam 2010a, b on a related phenomenon that leads to new the stratification of the academic profession: "the new majority of non-tenure-track faculty in higher education").

In the competitive labor market for young potential entrants to the academy, the role of academic mentors, apart from the role of research achievements, emerges as an important issue. Regardless of the legal and institutional status of young researchers, they need an academic mentor who provides them with intellectual support during the entire research process leading to a $\mathrm{PhD}$ thesis. And they need 
mentors beyond doctoral studies, in a transition period potentially leading to university employment.

The interviews indicate that the cornerstone of the academic career is to be "discovered" by, and to be "invited" to work with, the right academic (institutionally, a professor and intellectually, a mentor; there is a "process of motivated search" between masters and apprentices, Zuckerman 1977/1996, p. 107). In other words, "meeting the right academic" does not have to be a random incident; for the most able doctoral students, it can be a mutual intellectual discovery based on social interactions in the academic setting, gradually leading to building partnerships in research between senior academics and most talented, ambitious and hardworking students or doctoral students with specific knowledge, skills and attitudes. A good fit in norms, values and attitudes (which can be referred to as a Mertonian "academic ethos") between mentors and their protégées is as important in view of young academics reflecting on their successful paths to the university as traditional academic achievements as viewed through the proxy of publications in competitive journals. As reported in Austria, "after graduation I was invited by my professor to work full-time on a research project as a doctoral candidate" (AT23_AC), or "for the first contract I was selected from among many, I was doing well, with high marks; it was also a consequence of my good relationships with professors" (CH11_AC).

Invitations to be employed are also important. As a Romanian junior academic reports, "the coordinating professor of my bachelor degree asked me whether I would like to follow an academic career, and thus I competed for the university tutor position" (RO55_AC). A Croatian junior academic points out that "during the hiring process, apart from the formal conditions (grade average) it was necessary for a teacher taking an assistant or a junior researcher to know the person he is hiring as his student because in this way the person had a bigger chance of being employed than someone who applied for the position from the 'outside'. For further advancement, [though], the most important criterion is a number of published works" (CR2_AC; the Croatian system is reported to be "very closed in that sense because it rarely (almost never) allows an individual outside the system to enter it", CR3_AC). Thus social networking abilities and long-term trustful relationships with academic mentors are very important to succeed in competitive academic markets for young doctoral holders (which is not largely different from the past, as reported by Logan Wilson with reference to best American universities in the post-war period (Wilson 1942/1995, 1979)).

In most general terms, little has changed since Wilson wrote in his Academic Man:

entering university work as a life career is very much like entering matrimony: everybody agrees that it is an important event but so many intangibles are involved that nobody knows exactly how it happens. The candidate must choose and be chosen, and despite the indeterministic beliefs of a democratic society, chance and the pressure of circumstances are just as decisive as sentiment and rational choice. (Wilson 1942/1995, p. 15) 
Many academics interviewed across Europe relate their academic careers to what they term "chance", "luck", "accident" or "opportunity" ("at the foundation of my academic career lie hard work and, last but not least, the opportunity", RO59_AC; or "but I also think luck plays an important role since there is a cap of how many academics can be promoted in a given year depending on the money available", IE55_AC).

The invitation to cooperate in research with the right academic and at the right time of the academic career opens a window of opportunity for young academics. Traditionally, promising students were approached by professors and invited to join their research groups. The criteria of choice, beside the academic merit, could be trivial but important from the point of view of interpersonal relations. As one of the interviewed academics stressed, the mentoring professor chose her "because they got along well on an emotional level" (AT55_AC). Nevertheless, the interviewed academics (mostly junior) underscored this particular moment of being an object of intellectual interest in their professional careers as a turning point that sparked their interest in research and made them seriously thinking about working in higher education in the future:

A critical point of my academic career was a meeting with the right professor, my mentor who directs me in the right way and also who has helped me to articulate my research plans and ambitions. (PL2_AC)

Professors seem to have the power that enables them to inspire, engage and guide juniors through early stages of their academic careers. They can also, especially initially, attune their minds towards some problems rather than other problems in research, as well as determine their general ways of thinking within disciplines they represent. According to interviewees, the influence of those mentoring professors cannot be overestimated. Their intellectual imprints are left through mostly informal, indirect, sometimes even intuitively given remarks, advices or guidelines. The mentoring professor often serves as a role model for young academics. ${ }^{1}$ These invisible but strong influences have been largely confirmed by junior academics who often declare that their personal successes in research would not be possible without the priceless and often immeasurable, both direct and indirect, contribution of their mentors. As reported, in an academic career, "the most important is the mentor who is taking care of everything. He or she is supervising and mentoring a career of a young academic, paving the way to grants, publications and fellowships" (PL1_MAN).

Meeting a good academic mentor is thus a milestone in an academic career. Academic mentorship is a difficult task to perform and requires specific personal

\footnotetext{
${ }^{1}$ As Harriet Zuckerman reported about the American ultra-elite of Nobel laureates, "as role models for the younger scientists, the masters sometimes led them to levels of accomplishment they could not ordinarily imagine for themselves. ... In part, the elite masters evoked superior performance by conveying through their own behavior a sense of how much could be achieved in scientific inquiry and what it was like to do scientific work of importance" (Zuckerman 1977/1996, p. 125).
} 
and professional skills, mutual understanding and strong willingness to cooperate on both sides of the relationship. Undoubtedly, it is a priceless experience for doctoral candidates who require intellectual inspiration and later on seek, often tacitly, various types of direct or indirect support and intervention in finding good, preferably full-time, employment in the university or public research sectors. There is another side of the coin, too: mentorship can support nepotism and lead to the cloning in the academia (see Blackburn et al. 1981). There are many complaints expressed by interviewees about unfair procedures of carrying students further along the academic route by their powerful mentoring professors. With regard to early stages of the academic career, interviewees underscored that finding a good academic mentor was a turning point in their professional academic careers (it might imply a dead end if the cooperation fails at some point). Apart from serving young academics with their academic expertise, research experience and academic networks, mentoring professors are often able to secure external funding for them. In some countries, there is high dependency of junior academics on senior academics based on project funding provided by the latter. On top of that, mentors can provide access to their scientific networks and young academics can rely on them while creating their own networks. It will benefit them in the future, although networking of young academics is reported to be difficult without the support of a well established scholar. Doctoral students know they need to belong to larger research groups to be successful: as a Romanian young academic emphasizes, "I need to belong to a consolidated research team because I am aware that this is the only way to achieve performance in research. [...] To be a member of a sound research team favors publication and has a positive effect on the academic prestige of scientists and on their capacity to train new researchers" (RO19_AC). Not surprisingly thus, "an academic career is based on professionalism, individual study, research, motivation and membership in a research team showing the highest possible academic prestige" (RO20_AC).

Finally, expectations from mentors are reported to increase upon the completion of the doctoral dissertation. The advent of a transitional period following the doctoral period verifies an institutional and academic position of mentors and their intentions regarding the professional future of their apprentices, or the employment of junior scholars. The reason is that, by and large, juniors expect some assistance in getting through the transitional period and in securing employment in the academic sector. As a Swiss junior academic pointed out, she became an assistant "because of good relationship with a professor who offered me to do a master $(50 \%)$ and work at university at $50 \%$. I got a lot of support from this professor, with whom I also did my bachelor thesis as well as my specialization year (i.e. third year BA)" (CH_7-AC). In an academic progression path, the initial period of doctoral studies leads to a transition period which for those who wish to stay in academia means seeking part-time or full-time, university-paid or projectbased employment in any part of the national (or international) system. The international mobility of doctoral students and doctoral holders in Europe has been substantially growing; one of the mechanisms used are Marie Curie Actions 
supported by the European Commission. The vast majority of young doctorate holders seek employment in national systems, though.

\subsection{Entering the Academic Profession, Among Growing Insecurity and Increasing Instability}

Following meeting the right mentor, the second milestone in the academic career comes when a decision to stay in academia after defending a doctoral dissertation is taken. According to interviewees, young academics are hold in abeyance, and have to be highly competitive in their research achievements to be able to enter the academic profession. A mass model of doctoral training leads to a substantial increase in the number of doctoral degree holders, most of whom have no option but to search for employment outside higher education. Doctoral training systems are expanding faster than higher education systems and employment opportunities they provide, though. On top of that, even more than before, in massified systems the traditional rules about selectivity in academia still hold: and traditionally, "scientific ability is very unevenly distributed" and "research is not an egalitarian profession. It is a rigorous pursuit, where incompetent performance, as signaled by persistently low achievement, eventually clogs up the system" (Ziman 1994, pp. 258-259). Traditionally, most new PhD holders in Europe are inclined to work in the academic sector. Consequently, as often reported, "I definitely think that there is very big competition among the doctoral candidates" (German, junior, female). Under these circumstances, the transformation from the status of a doctoral student to any form of research-based or teaching-based employment is a critical moment in the career development. The number of new positions in all European systems studied is much smaller than the number of doctoral graduates wishing to stay in academia. Therefore a feeling of insecurity and instability is prevalent among doctoral students, as reported by young academics throughout Europe: "universities in Finland educate such a high number of PhDs at the moment. This of course leads to insecurity especially for those who want to stay in academia." (FI72_AC). Uncertainty is also reported among young academics working on parttime contracts (IE1_AC).

Despite worsening employment conditions (see Altbach 2000, 2002), the academic profession still remains an attractive option (Enders and de Weert 2009; Enders and Musselin 2008; Musselin 2007). Despite increasing and differentiated job expectations, often increasing teaching loads, especially for recent entrants to academia, relatively decreasing salaries (compared with other professionals), changing employment relations towards less secure, less stable and more often of a fixedterm nature, despite uncertainty as to future developments of the university sector in Europe, higher education still attracts very talented people (see Kwiek 2009 on the "changing attractiveness" of European higher education sector). Higher education in Europe today is still attractive as a workplace even though it is a long way from what 
Wilson described in the mid-40s as "reasonably secure tenure, public esteem ... pleasant work and surroundings, sufficient leisure for the pursuit of personal interests, and so on", (Wilson 1942/1995, p. 21). As the result of the survey conducted in the CAP project shows, working in higher education can still offer an interesting perspective for professional path development, and job satisfaction levels in European universities are relatively high, and consistently so almost throughout the continent (Kwiek and Antonowicz 2013). As stressed before, there is an oversupply of good candidates to enter the academic profession and an undersupply of academic positions in stagnating systems. Consequently, there are increasing controversies about academic recruitment processes, for instance, as reported in Austria, "there is a 'mentality of local emperors' at this university, as heads of departments and professors have the power to decide on tenure-track positions relatively autonomously. The advertisement for an open position is an official act, but the texts are mostly tailored to certain candidates" (AT44_AC). Or as reported in Germany, "there were several candidates for this position, but through consultation with the professor it was clear that when I am applying for this job, I will get this place" (D208_AC). Some changes increasing the transparency of hiring processes for young academics are reported but they are slow; in general, both the research promise, research track record and the notion of "choosing and being chosen" matter.

In more general terms, higher education cannot be regarded as a growth industry as automatically as three or four decades ago. What was taken for granted while seeking academic employment in the long post-war period of expansion of higher education does not have to be the case anymore. As John Ziman argued, ever since science became a regular profession in the late nineteenth century, it was "a buoyant open-ended enterprise, where talented newcomers were welcome, and where they could look forward to opportunities for personal advancement right through their working lives" (Ziman 1994, p. 167). The ever-expanding higher education and research systems used to be a "growth industry" for three centuries now - but this feature does not have to be a defining one for the future. Some countries, such as Poland and several other Central European economies, face significant contraction in student numbers, leading inevitably to the contraction of university-based academic profession (Kwiek 2013a; Antonowicz 2012a). The rules of the game of entering the academic profession and of the progression in the academic career may be expected to be fundamentally different in the times of stagnation (or even contraction) from those holding in so far ever-expanding European systems.

Academic careers are linked to public universities, that is, by extension, to sustained public funding. And rationales for public funding in higher education have been evolving in the last two to three decades, as the postwar "social contract" between governments and universities, most clearly expressed in Vannevar Bush's report on Science: The Endless Frontier (Bush 1945; Kwiek 2013a), has been under revisions. As summarized by Martin and Etzkowitz (2000, p. 7),

under the revised social contract there is a clear expectation that, in return for public funds, scientists and universities must address the needs of 'users' in the economy and society. Furthermore, they are subject to much more explicit accountability for the money they 
receive. In addition, implicit in the new contract is a much more complex model of innovation than the previous linear model, unfortunately making it much harder to persuade politicians of the merits of increasing public spending on research!

The rules of the game may be increasingly different for different research areas because, increasingly in the last few decades, "the only arguments that now seem to carry any weight for the expansion of science are those that emphasize its promise of future wealth or other tangible benefits" (Ziman 1994, p. 85). Knowledge economy makes some types of university-produced knowledge (for instance, what Williams terms "economically useful knowledge" or "economically valuable codified knowledge”, Williams 2012, pp. 20, 34; see Brown et al. 2011) much more relevant than other types. Expansion in some areas of higher education, and some areas of university knowledge production, may be accompanied by contraction in other areas of both higher education and university knowledge production (see Kwiek 2013a; 2011). The geography of study areas and, consequently, also the geography of academic posts available, has been systematically evolving. In some countries, the evolution has been clearly guided by new national strategies for higher education and innovation, and by new "competitive" research funding regimes accompanied by new science policies (Geuna 1999).

Knowledge economy changes the shape of student choices in higher education, as wage premium for higher education is increasingly related to academic fields. The impact of the growing evidence that "not all graduates are being eagerly sought by employers to contribute to a knowledge economy" (Williams 2012, p. 33) on the future differentiation of the academic profession (by academic disciplines) is still unclear; the impact of national science policies on national research funding is already perceptible, though, and often viewed as a threat to the future research funding for, especially, social sciences, arts and humanities. And research funding is used both for research performed by those already working in academia and for fixed-term positions for new entrants.

In very broad terms, so far, the history of science was that of rapid, unimpeded growth:

Ever since modern science 'took off' in the seventeenth century, it has been a growth industry. Knowledge and technical capabilities have not only accumulated steadily: the rate of accumulation has also accelerated over time. The scale of all scientific and technological activities has continually expanded. Every measure of these activities - numbers of people engaged, resources employed, output of published papers and patents, commercial and industrial impact, etc. - seems to have been increasing exponentially for the best part of three centuries. (Ziman 1994, p. 67)

But this history may have been exceptional. The growth of science is linked to the numerical expansion of universities, and the numerical expansion of academic posts available throughout European universities. Long-term and large-scale changes in rationales for public funding for research may have a delayed impact on the academic career opportunities. The latter are a significant part of the former.

As strongly as ever before, staying in higher education after completing their doctoral dissertations becomes an ultimate goal for those who think about being full-time academics. The tenure-track is a tempting career opportunity and the 
transitional period following the period of doctoral studies is decisive about whether the person will stay in academia, and in which part of it. Some interviewees tend to believe (and experience) that the real selection in the academia takes place shortly after completing doctoral dissertation. "It is most critical to quickly obtain a position immediately after the doctorate, even if it is not a permanent position. It makes it possible to establish networks in the framework of regular employment" (AT50_AC). For some academics, this is the most decisive moment in their careers, a sort of "do or die" period. Reaching this milestone requires making preparations in advance. Good scientific publications, in current competitive environment, may not be enough to enter the academic profession. Also other personal assets are very useful; they include well developed social skills and social networks built during doctoral studies. As a Swiss junior academic declared "you need to be 'promoted' individually, personally, your work has to be clearly visible" (CH17_AC). Today, most of early stage career opportunities in higher education require external project funding or other external financial contribution and therefore young academics believe in getting on well with professors who have access to financial research resources and the power to distribute them. In some countries, both social networking and, perhaps surprisingly, teaching and pedagogical abilities seem to count more than ever before: "People are appointed to professorships on a strange basis. Advancing in an academic career was previously based on the quality of your research and its relevance in an international context. But now we have started emphasizing pedagogical merit more and more. Also, your social competence and your social networks are becoming increasingly important. This is of course a diffuse criterion and very difficult to measure. I am little bit worried about this development" (FI77_AC). Social networking, especially international, is believed to matter substantially in successful fundraising for research. As a senior lecturer from Ireland points out, "there is a huge emphasis now on research and acquiring research funding. But academics in the current climate cannot get funding if they apply on their own or with a couple of colleagues from their department. Instead, you bring in people from all over you know Europe or the world, different disciplines, different countries and that's how you get funding these days" (IE7_AC).

The mobility between the higher education sector and the economic sector is often difficult, especially it is hard to start academic career later on in professional career, coming from the business sector. Entering the academic profession today most often means entering it right after the doctoral or postdoctoral period, without prior experience in the business sector. In some countries (e.g. in Poland or Romania), it is very rare to succeed in coming back to the academia after early departure to the business world. It stems from the fact that the professional career development path is based on cumulative promotion and cumulative research achievements and lagging behind in measurable research output can be difficult to overcome. In addition, academic achievements are an important criterion in competitive research bids and calls for research proposals and research fellowships. The probability of getting research funding in a competitive environment without accumulated prior research achievements is low. Some higher education systems 
are more open to intersectoral mobility; other systems (e.g. Polish or Romanian) are almost closed for the outsiders and the mobility into the higher education sector for latecomers or for practitioners from the business world is of marginal importance for the system as a whole (as it was in the 1990s and in the 2000s, see Kwiek 2003; 2012b).

In European universities with more hierarchical institutional settings, with very limited chances for career progression for junior researchers, or with a limited (and in some countries, decreasing) numbers of senior academic posts, the intersectoral mobility is almost always in one direction: from universities to enterprises. Although full-time returns from the business world to academia seem difficult, some part-time returns (e.g. sharing practical knowledge derived from company experience) still seem possible. In general, they are still reported as rare. Most European institutions do not consider work experience outside of academia as important in their staff recruitment procedures. To the question "to what extent does your institution emphasize the following practices" (Scale of answer $1=$ Very much to $5=$ Not at all) - "Recruiting faculty who have work experience outside of academia" - the answers 1 and 2 varied substantially across countries, from $7 \%$ in Italy to $39 \%$ in the Netherlands, with the lowest scores in Italy, Poland, and Norway, and the highest scores in Portugal, Germany and the Netherlands. The cross-country variations are given below in Fig. 3.1. What it means in practical terms is that institutional norms and values, and institutional practices associated with them, do not support the arrival of new faculty from the business sector; the signal sent to doctoral students and postdocs across Europe is to start an academic career as early as possible, without delays in other sectors. Work experience gained outside of academia is reported not to be highly valued by academic institutions. The universal, direct transition between the doctoral and postdoctoral periods and the employment in the higher education sector makes the competition for jobs more fierce than it would be with the intersectoral business sector/higher education sector mobility being more institutionally accepted.

The transformation from being a doctoral student or a postdoc to being an academic means passing through a rigorous selection process; a successful passage to academic employment is a turning point. Therefore entering the academic profession in any form becomes an ultimate goal and the following statement reflects the spirit of this transitional period: "it was more important to get a foot in the door of the university than anything else" (AT46_AC). And one should not be surprised that academics interviewed declared that "in my personal career, the phase of the dissertation was decisive, not so much the phase of habilitation" (AT25_AC).

\subsection{Steps Towards Full-Time Employment}

Thus the next critical turning point of the academic career is obtaining full-time secure employment in the higher education or research sector. There are significant differences across European countries studied because obtaining permanent full- 


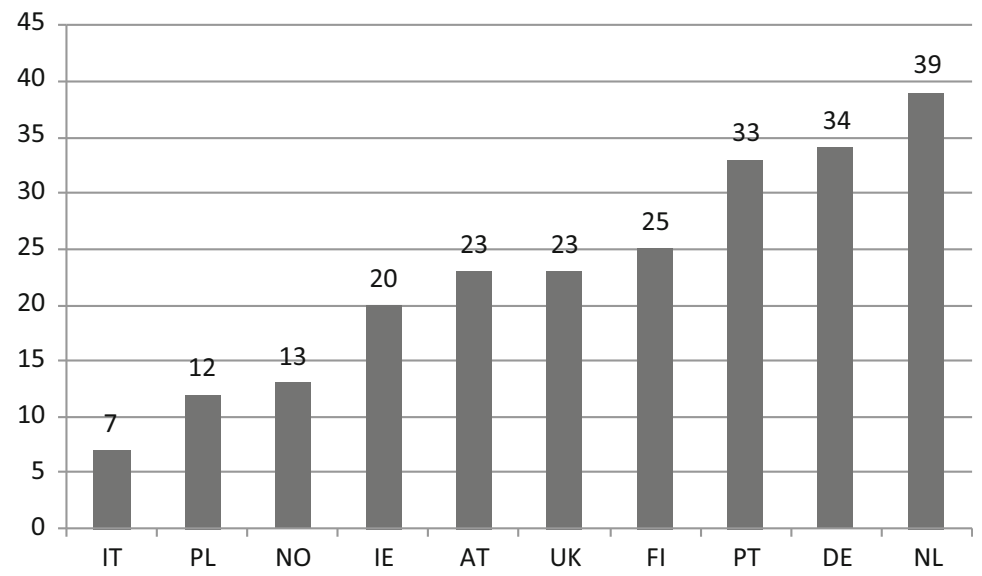

Fig. 3.1 Intersectoral mobility: faculty recruitment with prior non-academic experience (percent; responses 1 and 2 only). Question E6: To what extent does your institution emphasize the following practices? (Scale of answer $1=$ Very much to $5=$ Not at all): "Recruiting faculty who have work experience outside of academia". Count: $\mathrm{n}(\mathrm{IT})=1,622 ; \mathrm{n}(\mathrm{PL})=3,424 ; \mathrm{n}(\mathrm{NO})=871 ; \mathrm{n}(\mathrm{IE})=$ 794; $\mathrm{n}(\mathrm{AT})=1,113 ; \mathrm{n}(\mathrm{UK})=796 ; \mathrm{n}(\mathrm{FI})=1,173 ; \mathrm{n}(\mathrm{PT})=960 ; \mathrm{n}(\mathrm{DE})=1,001 ; \mathrm{n}(\mathrm{NL})=688$

time positions in higher education requires meeting different formal criteria. In a few countries (e.g. Poland), the professional stability and secure employment come almost automatically with the habilitation degree. Stability and security have traditionally, throughout the whole post-war expansion period in European higher education, been crucial factors in attracting able individuals to the university; as Bowen and Schuster pointed out long ago, with reference to the US system, "the excellence of higher education is a function of the kind of people it is able to enlist and retain on its faculties" (Bowen and Schuster 1986, p. 3). Hence, in this respect, the habilitation becomes naturally a milestone in an academic career in those systems where it still exists both in theory and in practice. For instance, in Poland

the existing hierarchy resembles a feudal hierarchy and everyone knows his or her place in it. In public universities, this hierarchy is overemphasized and obtaining the habilitation degree implies obtaining a significantly different status at the university. (PL25_AC)

Or, as remarked by a Polish junior academic, "the so-called community of academics is in fact comprised of two completely different groups: senior and junior academics. The difference is not only in status in the organization, it is much more than this. Habilitation is a turning point in any academic professional career, it changes working habits, lifestyles, and sometimes also friends. There is a huge difference between senior and junior academics in Polish higher education" (PL8_AC; "feudalism in higher education is common form of relationship. And taking advantage of junior academics by senior academics is well rooted in some disciplines such as medicine" PL15_AC; see Kwiek 2014b). Nevertheless, European academics still live in what Wilson termed "an open-class society: entry into their occupation is more accessible than in most other professions, and 
advancement in it is closely coupled with individual capability and effort" (Wilson 1979, p. 206). Higher education working environment is tough and highly competitive - but it seems to be fair across European systems.

In Poland, representing systems with habilitation, there is a significant difference in status within the academic community between academics with the habilitation degree and those without it. In this hierarchical community, the habilitation is a dividing line between two clearly distinguished, and often not interacting, groups of academics. In interviews, academics (particularly juniors) often refer to this stratification as "a two class-society", "a caste system", a "pyramidal structure" or even more often as "a feudal society": "The relation can be very feudal - young academics are forced to write doctoral dissertation on the topic that one has neither knowledge nor interest in it. But this is the way it should be done and if one has no knowledge about a given topic, she needs to work harder to get one". (PL7_AC). Or as stressed in another interview, the relation between senior and junior academics is "underpinned by the old system [the communist system that existed in Poland 1945-1989]. Maybe there is no more 'cooking dinners and baking cakes' for professors but there are still elements of it from the past" (PL29_AC).

Regardless of which description we choose to apply to describe the relation within the academic community in Poland, they demonstrate the fundamental importance of the habilitation degree in the higher education sector in Poland. In a highly stratified community, obtaining the habilitation degree is a milestone in an academic career. It guarantees remarkable growth in both social and academic status and also (almost automatically) provides a permanent full-time university post. For many, it is the termination of a long period of professional uncertainty (traditionally in American universities, the period of uncertainty was short due to "up or out" policies: in case of instructors, the lowest rank in the academic hierarchy, "the tenure is brief or uncertain, the turnover highest, the remuneration lowest, the criteria for advancement vague or confused, the duties manifold, and the future full of doubts. ... The mental anxiety may be prolonged by repeated shortterm appointments, with the threat of eventual failure of renewal hanging over the instructor after 7 or 8 years of service", Wilson 1942/1995, p. 61). But there are also other countries (e.g. Finland, Austria, and Switzerland) in which the habilitation degree or different forms of academic seniority do not guarantee a higher academic status and secure employment. It does open more opportunities for applications for full-time permanent positions at higher education institutions but there is little doubt that there is still a long way to go to have secure employment in these countries. The Bologna structure of higher education has made doctoral schools much more accessible for young researchers. The advent of doctoral schools and a mass model of doctoral training largely dismissed the idea of apprenticeship in the academia and the selection to become faculty members have been moved up to post-doc or junior professorial level. "Competitive evaluation and selection are structured processes from the (tenure track) professor assistant on: we check for quality according to publications, i.e. research, and teaching quality, too. We ask for four to six references" (CH19_MAN). 
The significance of obtaining secure employment as a milestone in the academic career is hardly questioned in contemporary academic world. There is strong evidence that there is a huge gap between academics with fix-term contracts and those with permanent ones. "At the university, there is a two-class system of those who are on permanent positions and those who know they have to leave the university eventually" (AT39_HEP). The process of marketization of higher education (Jongbloed 2003) also involves transformations of academic employment relationships. As the modernization and expansion of European higher education proceeds,

the working life of institutions has evolved from one rooted in maintaining the privileges of a self-governing academic elite to one centered on recruiting, rewarding and managing a diverse academic workforce in ways aimed at meeting the mutual needs of both employers and academic staff in the employment relationship. (Farnham 2009, p. 212)

The direction of transformations in the last two decades most often implies less stable, less secure and less attractive working conditions in higher education. "Academic career has previously been very clear but now it is very uncertain" (FI15_AC). Some academics are employed on externally funded positions for quite a long time, they try to apply for university positions: "they are not happy. To have to finance yourself on the basis of external funds, it is not easy. The sword of Damocles of not knowing if you will be employed the next year is hanging over them" (AT10_AC). An increasing number of employees work under fix-term contracts and they can easily be dismissed if needed without extensive social and financial costs. Egbert de Weert (2001, p. 78) calls this approach a "zero-appointments" policy that leads to "invisible faculties". Therefore a transition from fix-term employment to a full-time permanent position becomes a milestone in academic career and also an ultimate goal for many academics. "Even in Germany among people with habilitation, limited term jobs have increased" (D201_AC). Fixed-time contracts may also limit effectively the access to research funding: as reflected by an Irish junior academic, "The current academic contracts are of 5 year duration which impacts greatly on an early career academic's ability to apply for research funding because most research funding requires permanency or at least that the academic will remain in that post for the duration of the grant. Moreover, the employment of post-docs is also prevented under the moratorium, so the profession of academia is actually currently suspended. The newer members that are coming in are operating in a much different role (there is a sort of 2-tier system) and I can't call that a profession anymore" (IE39_AC).

In most countries academics express their complaints about recent staff policy changes in higher education which reduce access to permanent posts. As one of Austrian senior academics stated, the acquisition of well-funded research projects makes "future fantasies of a permanent position" emerge. A secure position in a higher education institution becomes a personal goal. It is generally expected that the availability of permanent posts in higher education institutions will decrease over time and will become a subject of increasing competition between academics. "There is a huge competition for available posts. More and more is needed in order 
to get a post" (FI25_AC). Moreover, financial austerity plans introduced in some European countries and major cuts in public spending in higher education may foster this competitiveness of the academic working environment and make secure full-time employment more difficult to achieve. Policy changes put many academics in a very difficult professional position because at least some of them like a Finish senior full-time academic interviewed - "has a permanent position outside university, and he will keep it because university cannot offer him a permanent position. He has achieved what he wanted, although he would like to be a docent one day" (FI14_AC).

\subsection{New Pressures in Changing Organizations and Reforming Systems}

Academic careers are becoming more versatile and involve a wide range of different criteria to develop, although scientific recognition, especially through internationally visible publications, are still the core of the academic career that defines academic trajectories. Interviewees report a widespread trend that might imply a departure from a career model based on a limited number of milestones (often associated with various academic "rites of passage") toward a new pattern called by one of them "cumulative promotion": "criteria for academic careers in the 1970s and the 1980s were "not to fall out of favor with the one or two professor (s) that supported you as a young researcher', today (over the last 5 years), measurable scientific qualifications and international experience are required" (AT33_AC).

Job instability grows, causing lots of controversy inside the academia. "Academic career is based on quality work and ambition but academic career is nowadays very unstable and unforeseen" (FI4_AC). There is widespread feeling of increasing pressure to produce highly-cited publications in peer reviewed journals and to gain international experience for the academic career to progress. It is also important to publish extensively in highly respected journals. However, it has also been a commonly shared feeling that to get good publications, academics need to have to be able to acquire external funding and to be building networks in the academic community. "There is external pressure to do research, to attract funding, to update the research profile and to do the student surveys for quality assurance purposes; however, the internal pressure of self-motivation is even greater. Main challenge is having many balls to juggle in terms of teaching, research, administration, working for external bodies and helping in moving the university forward" (IE53_AC). Interviews show some concern and disbelief in modern indicators of academic performance. "Meritocracy: always too little! Also in science. Publications seem to be more meritocratic, but it is a jungle there, too. How can you measure? Publications, impact factors. . quality is only linked to peer review" (CH12_AC). 
According to those who welcome a new system of internationally comparable, increasingly measurable research output used for both career progression and research funding opportunities, academics from the old system (for instance, as in this case, Austrian associate professors with permanent civil servant status) still "do not have to worry about anything" (AT01_AC). A new model based on increased professional insecurity is an attempt to make them more active in research, publications and also in acquiring funding from external sources. There is growing selfmotivation is securing research funding: "the pressure to get external funding comes primarily from within although it also comes from the school, the pressure comes from the university but the support comes [also] from the university" (IE54_AC). "The university careers used to be more linear than nowadays. Nowadays, a broader positioning is required" (such as foreign languages, interdisciplinary orientation, and external funding) (D120_AC). Indeed, as Schuster and Finkelstein (2006, p. 188) report in an American context, "the expectations about one's career prospects that an entering academic could have reasonably entertained a generation ago differ strikingly from current realistic expectations. The passageways have become bumpier". But, at the same time, they do not come as a surprise the evolution of expectations from European academics have been in progress from between one and three decades, with the longest experience of reforms perhaps in the case of the UK system. European academics are functioning in universities under permanent conditions of adaptations to changing environmental settings, in different countries to different degrees. The changing social, economic, cultural and legal settings of European higher education institutions increasingly compel them to function in the state of permanent adaptation; adaptations are required as responses to changes both in their funding and governance modes. The reforming of universities does not lead to reformed universities, as examples especially from major postcommunist higher education systems studied show (in particular, see Polish and Romanian interviews). In general terms, policymakers, following New Public Management lines, tend to view universities, like other public institutions, as "incomplete"; reforms are intended to make them "complete" institutions (Brunsson 2009). Reforming is thus leading to further waves of reforms (Maassen and Olsen 2007). ${ }^{2}$ And academics constantly need to adapt to changing institutions which are in turn adapting to ever-changing environments (see Teichler 2007; Teichler and Yagci 2009; Kwiek and Kurkiewicz 2012; and Kwiek and Maassen 2012).

A new general context for universities is that the social trust in public institutions can no longer be (automatically) guaranteed, which is a substantial change of social mood prevailing in postwar Europe, with relatively lavish public funding

\footnotetext{
${ }^{2}$ As organizational research shows, there is no surprise that reforms based on "simple prescriptive models" seldom succeed in achieving their aims: "such reforms often increase rather than decrease the felt need, and probability of, new reforms.... it is often observed that organizations work well precisely because naïve reforms have not been implemented" (Brunsson and Olsen 1998, p. 30).
} 
guaranteed and high social prestige of public universities and of the academic profession taken for granted. Traditional academic values, closely associated with the public service responsibilities of universities and science, Scott argues, "have to come to terms with a new moral context in which the superiority of the public over the private can no longer be taken for granted" (Scott 2003, p. 299). ${ }^{3}$ This new "moral context" has been widely supported by emergent EU social policies, especially social policies advocated in CEE countries, experimenting widely with various forms of privatization of social services (Kwiek 2012a, 2013). European institutions need to continue its reliance on traditional academic values (especially academic freedom and institutional autonomy) to be attractive. As Bleiklie, Høstaker and Vabø conclude,

[s]ome sort of contribution to society has always been demanded from the universities in return for a certain degree of autonomy and public funding. What is arguably at stake today is that a less clearly delimited definition of the nature of the universities' contribution to society pose a potential threat to their autonomy. ... One reason for the resilience of the university institution is that universities have at one and the same time been able to sustain sweeping change and protect their core functions. However, past resilience is no guarantee against future decay. (Bleiklie et al. 2000, p. 307)

The status quo - or the current social and economic modi operandi of universities in Western societies - is very fragile: the multi-faceted impacts, trends, and challenges are far-reaching, long-term and structural in nature (see especially Maassen and van Vught 1996; Altbach et al. 2009; Kogan and Teichler 2007; Kwiek 2013; Antonowicz 2012b). The durability and stability of institutions, even in periods of major reforms is, however, that "institutions are not simple reflections of current exogenous forces or micro-level behavior and motives. They embed historical experience into rules, routines, and forms that persist beyond the historical moment and condition" (March and Olsen 1989, pp. 167-168). The fragility of the status quo is widely reported in all European systems studied.

Organization studies show that no matter how strong external discourses surrounding the institution are (here: global, transnational and EU-level discourses), the potential for changes and a range of possible reforms is always relatively limited, and the period for institutional adaptation - relatively long. It is therefore difficult to assume that the intentional direction of changes in the academic sector as a whole will coincide with their actual direction of changes. Often in the history of the university (see Rüegg 2004), significant scope of changes remains determined on the one hand, by redefined tradition, and, on the other hand, by sheer contingency. "Great expectations", as shown a quarter of a century ago by Cerych and Sabatier (1986), often lead to "mixed performance". At the same time, policymakers tend to view institutions, higher education institutions included, as "incomplete". Reforms are renewed attempts to make universities "complete"

\footnotetext{
${ }^{3}$ As Kezar (2001, p. 9) rightly argues from the perspective of organizational studies, "what needs to be preserved may be just as important to understand as what needs to be changed" and "balance between calls for change and tradition may be desirable".
} 
organizations. At the level of academics, directions of changes are often unclear, rationales behind them remain often undefined, and reforms (especially in the three postcommunist countries studied) are viewed as a step in a series of reforming steps only rather than as a point of arrival. In ongoing reform initiatives throughout Europe, there is a hidden dynamics of changes in relationships between the state, or the major sponsor of teaching and research, and academics, or the major beneficiary of state sponsorship of the academic enterprise. The academic profession has a fiduciary role to play: constitutive rules and practices are not easily changeable, they take time to root and take time to change. Especially senior academics often view themselves as depositories of traditional academics rules, norms, and values, while junior academics know the traditional rules from their older colleagues but have to play according to redefined rules if they want to follow their own career steps.

Academics report to be undergoing regular evaluations that cover various aspects of their work but focus mainly on three areas: research, teaching and administrative tasks (or service, or engagement with both the university and its environment). Evaluations are often continuous and built on transparent, quantitative, measurable and comparable criteria. "The evaluation process becomes an integral part of the academic professional development from the beginning (almost) right to the end and therefore the pressure of continued evaluations is increasing" (D901_AC). It implies that the evaluation is attached to both academic degrees structure and to institutional positions in universities. It carries very concrete advantages in the academic setting: the existence of a foreseeable career path with predefined procedures.

Nowadays even a lot of publications in A-journals is not enough. You have also to be able to raise a lot of project funds. You also have to be able to popularize your scholarly work and have a lot of contacts with your students' future employers. Sometimes it feels like measuring these academic activities has become more important than activities themselves. For instance, citation indexes have become too important in my opinion and they are not comparable enough between different subjects. (FI62_AC)

Interviewees also express a strong criticism of what they refer to as the "American model" of professional career development in higher education. They criticize "the devastating model of professional development" that is built on fierce competition, uncertainty, instability and ongoing evaluation of individual research outcomes. Each discipline or a specific field of research can develop their own unique lists of milestones. In other words, in the linear model of academic professional development, milestones are not really centrally defined, instead there is a range of opportunities to be taken by individuals and translated into milestones in their careers.

The traditional milestones of the development of academic career may increasingly be accompanied by a large number of small steps that must be taken regularly and which are regularly assessed. The frequency and regularity of evaluations make the academic career a linear and, to large extent, a predictable process. Milestones of professional development are spread over the entire length of the academic career, so that the small individual steps do not hold a critical "do or die" 
component. Switzerland provides a good example of this direction of changes: "elsewhere careers are established with points, so that you can plan objectives for the following years, here you only have salary increments" (CH15_AC).

Perhaps the most important element of the academic career is the tenured position. It gradually becomes nothing more than the final stage in the academic professional development, available to some. Obtaining a tenure position (if one exists in the system) is a natural culmination of the research track record and sometimes also previous teaching achievements. Interviews show that there is a strong criticism among European academics of taking a too narrow "research only" perspective of the academic promotion, in particular for tenured positions. Finland, for instance, introduced a broader approach to criteria of recruitment of professors, taking into account also other aspect of academic work (e.g. teaching) but this direction also caused some criticism.

I think the recruitment to professorships is way too arbitrary. I could tell many stories of
really talented young scholars who were mistreated in Finland and will now work abroad
for good. We cannot afford that in a country with only five million inhabitants. I think a new
Finnish tenure track system is completely wrong. It is a slap in the face of all those
doctorate holders that aren't professors and completed their degree more than five years
ago. (FI58_AC)

The academic profession is becoming increasingly competitive not only for new entrants but for all academics, at all levels of seniority. The competition for funding and prestige gets tougher and fiercer. "Because of the shrinking funding base, the academic profession will become, at least in some disciplines, extremely competitive" (CH29_MAN). In some countries (e.g. Germany), even tenured positions do not take the pressures off academics' shoulders.

The competition is becoming a normal dimension also for the youngest, it is a daily business: by means of transparent procedures, everybody is able to understand where she stands, why she was not appointed, etc. This has to be made explicit. Then there is competition for third means, like at the SNF and at foundations. (CH26_MAN)

Even in the countries with the chair system (such as e.g. Austria and Germany) in which professorships used to be traditionally well established positions at universities, there are radical changes ongoing. As a German professor stressed, "those who habilitate got under a strong pressure because they need to do their own external fundraising, and teach on their own, too" (D118_AC).

\subsection{New Demands and Mission Overload}

The competition to enter the academic profession and to stay in it, especially at lower levels of academic seniority, is accompanied by growing expectations in both research output, external research fundraising, teaching, and various service missions (surprisingly, in post-communist higher education systems of Poland, Croatia and Romania, various types of third mission activities are rarely mentioned and the 
major divide in academics' time allocation is between teaching and research, with a frequent conclusion that the two should ideally be "in balance" (RO37_AC)). Universities under conditions of massification across Europe are increasingly expected to be meeting not only changing needs of the state but also changing needs of students, employers, labor market and the industry, as well as regions in which they are located (Pinheiro et al. 2012; Benneworth and Jongbloed 2010; Kwiek 2012b for Poland). Demands put on academics are increasingly conflicting, universities are caught in what was termed "mission overload" (Jongbloed et al. 2008). Globally, for the vast majority of academics, the traditional combination of teaching, research, and service is beyond reach anyway: as a whole, globally, the academic profession is becoming a predominantly teaching profession; gravitating toward more emphasis on teaching is also the case, to varying degrees, in both Europe and in the US (Schuster 2011). In terms of criteria for promotion in European systems, research output is a critical factor. But there are systems (such as Ireland) in which all three university missions count, and where teaching and service may weight more than research (for youngest academics). As reported, "the criteria for promotion include research, teaching, and contribution (to the department, the faculty, the university and then to the wider community). For any promotion you are judged under those three headings. For a promotion from CL [career lecturer] to SL [senior lecturer] the weighting is 40 (Research), 30 (Teaching) and 30 (Contribution). For a promotion from SL to AP [assistant professor] there is more emphasis on research so the weighting is 60-20-20" (IE7_AC).

European universities have to be able to meet sometimes conflicting, differentiated needs (see Jongbloed et al. 2008 about "interconnections and interdependencies" of higher education communities and Kwiek 2009 on the "changing attractiveness" of the academic career). These needs sometimes seem to run counter the traditional twentieth-century social expectations from the academic profession in continental Europe, though. New expectations from universities impose on universities "unlooked for, and perhaps unrealizable, roles and responsibilities", as Shattock (2009, p. 1) notes:

Universities - endowed as they are with a long history and as important as they have been in
the production of scholarship and new ideas, and for the training of elites - have not until
recently been seen as such positive vehicles for economic progress. Like many other
institutions they are facing pressures for change and, unlike most other institutions that
have historically depended on the state for resources, their history suggests that they
operate most effectively if they have a high degree of academic and managerial autonomy.

European academics are working in changing institutions, characterized by both demand overload and mission overload. What is theorized at the level of national policies across Europe, academics actually experience on the ground - where teaching, research and service missions are fulfilled. They are most often unable to term the ongoing change processes but they can clearly refer to them as they are changing their working habits, lifestyles, and job satisfaction. What we can see today as universities' missions seems to have been highly influenced by the two decades of reformulations (both in theory and in practice) of the role of public 
sector services. In wider terms, the university, as other public sector institutions, is increasingly viewed in the context of economic competitiveness of nations, global pressures on national economies, and global pressures on national welfare states. For public universities, these are fundamentally new contexts; and they are new to academics as well (see especially Kwiek 2006; 2013a). Never before the functioning of the university has been so important both for the economy and for the huge (and historically unprecedented) numbers of graduates; it has never been absorbing so huge (public and private) financial resources. Also the social and economic expectations regarding universities (or their "relevance", see Geiger and Sá 2008; Skolnik 2005 and Välimaa 2008) have never been so high and so widely publicly formulated. As Bonaccorsi et al. point out (2010, pp. 1-2),

it can be said that the social demand placed on universities has increased significantly. These are great expectations of their ability to produce more education, more research, and more direct interaction with society and the economy. ... Policymakers are devoting more attention to the workings of universities and have introduced significant institutional changes in several countries.

Current economic expectations from universities compared with those from the 1960s cannot be met, and, from a historical perspective, as Skolnik (2005, p. 120) argues,

not since the 1960s has there been such strong and unqualified belief on the part of governments and the public in the vital importance of higher education to national economic well-being. However, in contrast to the situation in the 1960s, today the capacity of the universities to respond to these economic challenges and at the same time maintain a healthy balance between the economic and non-economic aspects of their nature is greatly jeopardized.

There is an "enormous demand overload" in European universities (Clark 1998, pp. 129-132), combined with "mission overload" (Jongbloed et al. 2008). As Clark (1998, p. 129, emphasis in original) argues,

\begin{abstract}
National systems of higher education can neither count on returning to any earlier steady state nor of achieving a new state of equilibrium. As principal actors within these systems, public and private universities have entered an age of turmoil for which there is no end in sight. Disjuncture is rooted in a simple fact: demands on universities outrun their capacities to respond. From all sides inescapable broad streams of demands rain upon the higher education system and derivatively upon specific universities within it.
\end{abstract}

Demands on universities, in practical terms, refer also to the demands on academics, leading to more busy academic lives. Academics report to be increasingly busy, and their professional stress is reported to be high (Kwiek and Antonowicz 2013). They increasingly work under pressure but, at the same time, pressure seems to be manageable:

Broadly speaking, I don't know if any academic is ever in control of everything. There are always many tasks to carry out such as setting and marking exam papers. An academic is in control broadly speaking but not on a day-to-day basis. [. . .] An academic firstly feels under pressure from themselves on the research side; to conduct research, get papers published, get grants, be seen to have an active research group. Then there is pressure from the 
administrative side of the role. The pressure isn't present to the extent that I am crumbling under the pressure; I can manage it so far and it peaks and troughs. (IE51_AC)

The pressure is manageable because while the professional stability is lower than in previous decades, requirements for particular steps in career ladders are more transparent and measurable today. It is perhaps easier to be planning the career based on more quantifiable, more similar across academic disciplines and across national higher education systems, indicators of academic progress. Perhaps the new rules of the academic game are tougher than ever before but at least they are advertized somehow in advance.

There is a clear difference with the past, as reflected by an Irish academic, "in order to get a promotion there are very clear criteria with regards to an academic's teaching, research/publications and service to the community. [It] was more woolly in the past, how you interpreted those criteria, whereas right now I think the criteria are very much laid down and very clear" (IE48_AC). In some countries changes are slow but unavoidable: as a Polish junior scholar reports,

the academic professional development path is very conservative. It lacks transparency and explicit criteria of academic promotion. Instead, there is a number of informal agreements between senior academics on what is required from junior academics to be awarded habilitation. This is understandable that not all criteria can be explicitly measured and benchmarked but the existing system does not build trust around the professional academic development path. (PL31_AC)

Or as another one reflects, "informal criteria established by cliques of professors keep the process of awarding academic degrees non-transparent" (PL32_AC). As of October 2013, though, based on a new law on higher education of March 2011, massive changes in both the procedures and the criteria for awarding both habilitation and professorship degrees will be introduced in Polish higher education. The direction of changes is towards meeting measureable, quantifiable criteria to avoid blocking academic careers through the above mentioned "informal agreements" on who deserves both degrees and on the basis of what past (predominantly) research achievements (on a recent wave of Polish reforms in the context of two decades of changes, see Kwiek 2014b; and on the role of internationalization in research in Poland, see Kwiek 2014a).

Only research has been traditionally related to prestige, and prestige-seeking is the core of the academic enterprise. ${ }^{4}$ Reputation is "the main currency for the

\footnotetext{
${ }^{4}$ There are inherent tensions between individual academic prestige and institutional prestige, though. At the institutional, rather than individual academic level, as Brewer et al. (2002, p. 147) point out (while analyzing their typology of institutions: "prestigious", "prestige-seeking", and "reputation-based"), the apparent paradox is that "prestige seeking promotes excellence on the one hand but can lead to excessive expenditures and unresponsive schools that neglect the needs of some undergraduate students and other customers who don't contribute to institutional prestige. ... the excellence toward which institutions are striving may have little to do with the satisfaction of basic customer demands. For schools trying to build prestige, there can be a negative impact on students either because this strategy induces resources to be diverted from their basic instructional function or because the costs lead to tuition increases that exceed inflation".
} 
academic" (Becher and Kogan 1980, p. 103; "much, then, of the driving force behind what academics do is concerned with building up, or maintaining, a professional reputation". ... "the pursuit of a good name in one's own particular trade") and it derives from research rather than from teaching (Clark 1983; Altbach 2007). In the developing countries, research and teaching have always been separated except for national flagship institutions. Further differentiated academic profession (s) can be expected to emerge in Europe, of which small segments than in the previous decades will be involved in (usually, in the higher education sector, statefunded) academic research. In the midst of transformations and adaptations, in order to flourish, which means to be both attractive and competitive, universities need to continue to be meeting (either traditional or redefined) needs of academics. Especially since the income gap between professionals employed in the private sector and academics employed in European universities has been growing: the best performing segments of the middle classes (Richard Florida's creative class or Richard B. Reich's symbolic analysts) have less and less in common with university professors, which today in many fields of science creates a huge problem of the generational replacement. The expected differentiation-related (or stratificationrelated) developments may fundamentally alter the academic profession in general, increase its heterogeneity, and have a strong impact on the traditional relationships between teaching and research at European universities. These processes across the Atlantic, in the Anglo-Saxon model, are already well advanced and widely studied in both research and policy literature.

\section{Conclusions}

Major milestones of the academic career in European universities, despite huge ongoing transformations and reform packages implemented throughout European higher education systems, remain the same. In general, they include the following: entering a doctoral program and completing it with a $\mathrm{PhD}$ thesis defense; finding a full-time or part-time job in academia; changing academic status from a junior to a senior one; and, finally, remaining in the system in a senior academic position. These traditional milestones are increasingly accompanied by continuous, small-scale steps, almost continuously assessed by both peer and administrative bodies. The academic labor market is becoming highly competitive, at all levels, rather than as traditionally, in lower academic ranks only. While successive milestones need to be reached, they result more often than ever before from a steady accumulation of research (and also teaching and service) achievements. The academic career ladder seems ever stronger linked to fundraising abilities and research funds made available; consequently, the role of academic mentors or patrons, willing and able to provide research funding to their protégés during the doctoral and postdoctoral career periods, seems crucial. 
Research is becoming both more interdisciplinary and more collective: junior academics are increasingly either employed or doing research in collaborative research projects headed by their academic masters. On the one hand, the academic career is much less stable and secure; life-time (or even long-term) academic employment can no longer be taken for granted, especially in the case of new entrants to the academic profession; on the other, though, it may be becoming more predictable through everstronger processes of assessment of quantifiable, comparable (both across disciplines and across higher education systems) and internationally measurable research outputs. Through an increasing number of small assessment steps taken in between the major milestones in academic careers, the academic progression is somehow less secure but more predictable. In competitive, less stable academic environments, both small steps and requirements for moving up the academic ladder may be becoming more uniform. The interviewees across European systems stress internationally visible research achievements and fundraising abilities as perhaps most important components for a successful academic life.

Viewed from a longer historical perspective, academics need to be more aware of processes exogenous to higher education but closely linked to its future, such as changing rationales for public research funding, a revision of a social contract between universities and governments closely linked to the postwar expansion of science in Europe, changing science policies guiding national research priorities, changing perceptions of the utility of research in knowledge economy, and diversified premium for higher education in contemporary economy across different study fields (as developed in Kwiek 2013a, a book providing a panorama of "knowledge production in European universiites"). Above factors have powerful impact on the current, and especially future, academic labor market, and particularly on its expansion in some areas and contraction in other areas. More volatile, rapidly changing economies certainly mean a less stable and more competitive academic world. ${ }^{5}$

\footnotetext{
${ }^{5}$ The qualitative material for this chapter comes from eight European countries studied in the project "Academic Profession in Europe: Responses to Societal Challenges" (2009-2012, funded by the European Science Foundation and coordinated by Ulrich Teichler and Barbara M. Kehm): Austria, Croatia, Finland, Germany, Ireland, Poland, Romania, and Switzerland. The material consists of at least 60 semi-structured interviews conducted per country. About 480 interviews have been conducted in total by national teams and they have been transcribed or summarized in detailed interview reports (for instance, the transcription of Polish interviews conducted by Dominik Antonowicz is about 800 pages).
} 


\section{References}

Altbach, P. G. (2000). The changing academic workplace: Comparative perspectives. Chestnut Hill: CIHE Boston College.

Altbach, P. G. (Ed.). (2002). The decline of the Guru: The academic profession in developing and middle-income countries. Chestnut Hill: CIHE Boston College.

Altbach, P. G. (2007). Tradition and transition: The international imperative in higher education. Chestnut Hill: CIHE.

Altbach, P. G., Reisberg, L., \& Rumbley, L. E. (2009). Trends in global higher education: Tracking an academic revolution. A report prepared for the UNESCO 2009 World Conference on Higher Education. Paris: UNESCO.

Antonowicz, D. (2012a). External influences and local responses. Changes in Polish higher education 1990-2005. In M. Kwiek \& P. Maassen (Eds.), National higher education reforms in a European context: Comparative reflections on Poland and Norway (pp. 87-110). Frankfurt/New York: Peter Lang.

Antonowicz, D. (2012b). Europe 2050. New Europeans and higher education. In M. Kwiek \& A. Kurkiewicz (Eds.), The modernisation of European universities. Cross-national academic perspectives (pp. 113-126). Frankfurt/New York: Peter Lang.

Becher, T., \& Kogan, M. (1980). Process and structure in higher education. London: Heinemann.

Benneworth, P., \& Jongbloed, B. W. (2010). Who matters to universities? A stakeholder perspective on humanities, arts and social sciences valorization. Higher Education, 59, 567-588.

Blackburn, R., Chapman, D., \& Cameron, S. (1981). Cloning in academe: Mentorship and academic careers. Research in Higher Education, 15(4), 315-327.

Bleiklie, I., Høstaker, R., \& Vabø, A. (2000). Policy and practice in higher education: Reforming Norwegian universities. London: Jessica Kingsley Publishers.

Bonaccorsi, A., Daraio, C., \& Geuna, A. (2010). Universities in the new knowledge landscape: Tensions, challenges, change - An introduction. Minerva, 48, 1-4.

Bowen, H. R., \& Schuster, J. H. (1986). American professors. A national resource imperiled. New York/Oxford: Oxford University Press.

Brewer, D. J., Gates, S. M., \& Goldman, C. A. (2002). In pursuit of prestige: Strategy and competition in U.S. higher education. New Brunswick: Transaction Publishers.

Brown, P., Lauder, H., \& Ashton, D. (2011). The global auction. The broken promises of education, jobs, and incomes. Oxford: Oxford University Press.

Brunsson, N. (2009). Reform as routine: Organizational change and stability in the modern world. New York: Oxford University Press.

Brunsson, N., \& Olsen, J. P. (1998). Organizational theory: Thirty years of dismantling, and then...? In N. Brunsson \& J. P. Olsen (Eds.), Organizing organizations. Copenhagen: Fagbokforlaget.

Bush, V. (1945). Science: The endless frontier. A report to the president on a program for postwar scientific research. Reprinted July 1960. Washington, DC: National Science Foundation.

Cerych, L., \& Sabatier, P. (1986). Great expectations and mixed performance: The implementation of higher education reforms in Europe. Trentham: European Institute of Education and Social Policy.

Clark, B. R. (1983). The higher education system. Academic organization in cross-national perspective. Berkeley: University of California Press.

Clark, B. R. (1998). Creating entrepreneurial universities. Organizational pathways of transformation. New York: Pergamon Press.

de Weert, E. (2001). Pressures and prospects facing the academic faculty in the Netherlands. Higher Education, 41, 77-101.

Enders, J., \& de Weert, E. (2009). Towards a T-shaped profession: Academic work and career in the knowledge society. In J. Enders \& E. de Weert (Eds.), The changing face of academic life. Analytical and comparative perspectives (pp. 251-272). New York: Palgrave. 
Enders, J., \& Musselin, C. (2008). Back to the future? The academic professions in the 21st century. In OECD (Ed.), Higher education to 2030. Volume 1: Demography (pp. 125-150). Paris: OECD.

Farnham, D. (2009). Employment relations in Europe: A comparative and critical review. In J. Enders \& E. de Weert (Eds.), The changing face of academic life. Analytical and comparative perspectives (pp. 195-217). New York: Palgrave.

Frank, R. H. (1985). Choosing the right pond. Human behaviour and the quest for status. New York: Oxford University Press.

Frank, R. H., \& Cook, P. J. (1995). The winner-take-all society. Why the few at the top get so much more than the rest of us. New York: Virgin Books.

Geiger, R. L., \& Sá, C. M. (2008). Tapping the riches of science. Universities and the promise of economic growth. Cambridge, MA: Harvard University Press.

Geuna, A. (1999). The economics of knowledge production. Funding and the structure of university research. Cheltenham: Edward Elgar.

Hacker, J. S., \& Pierson, P. (2010). Winner-take-all politics. How Washington made the rich richer - And turned its back on the middle class. New York: Simon and Schuster.

Jongbloed, B. (2003). Marketisation in higher education, Clark's triangle and the essential ingredients. Higher Education Quarterly, 57(2), 110-135.

Jongbloed, B., Enders, J., \& Salerno, J. (2008). Higher education and its communities: Interconnections, interdependencies and a research agenda. Higher Education, 56, 303-324.

Kehm, B. M. (2009). Doctoral education: Pressures for change and modernisation. In J. Enders \& E. de Weert (Eds.), The changing face of academic life. Analytical and comparative perspectives (pp. 155-170). New York: Palgrave.

Kezar, A. J. (2001). Understanding and facilitating organizational change in the 21st century: Recent research and conceptualizations. ASHE-ERIC Higher Education Report, 28(4), 1-9.

Kezar, A., \& Sam, C. (2010a). Understanding the new majority of non-tenure-track faculty in higher education. ASHE Higher Education Report, 36(4), 1-133.

Kezar, A., \& Sam, C. (2010b). Non-tenure-track faculty in higher education. ASHE Higher Education Report, 36(5), 1-91.

Kogan, M., \& Teichler, U. (2007). Key challenges to the academic profession and its interface with management: Some introductory thoughts. In M. Kogan \& U. Teichler (Eds.), Key challenges to the academic profession (pp. 9-18). Paris/Kassel: INCHER.

Kwiek, M. (2003). Academe in transition: Transformations in the Polish academic profession. Higher Education, 45(4), 455-476.

Kwiek, M. (2006). The university and the state. A study into global transformations. Frankfurt a/Main/New York: Peter Lang.

Kwiek, M. (2009). The changing attractiveness of European higher education. In B. M. Kehm, J. Huisman, \& B. Stensaker (Eds.), The European higher education area: Perspectives on a moving target (pp. 107-124). Rotterdam/Boston/Taipei: Sense Publishers.

Kwiek, M. (2011). Universities and knowledge production in central Europe. In P. Temple (Ed.), Universities in the knowledge economy. Higher education organisation and global change (pp. 176-192). New York: Routledge.

Kwiek, M. (2012a). Changing higher education policies: From the deinstitutionalization to the reinstitutionalization of the research mission in Polish universities. Science and Public Policy, 39(5), 641-654.

Kwiek, M. (2012b). Universities, regional development and economic competitiveness: The Polish case. In R. Pinheiro, P. Benneworth, \& G. A. Jones (Eds.), Universities and regional development. A critical assessment of tensions and contradictions (pp. 69-85). New York: Routledge.

Kwiek, M. (2013a). Knowledge production in European universities. States, markets, and academic entrepreneurialism. Frankfurt/New York: Peter Lang.

Kwiek, M. (2013b). From system expansion to system contraction: Access to higher education in Poland. Comparative Education Review, 56(3), 553-576. 
Kwiek, M. (2014a). The internationalization of the Polish academic profession. A European comparative approach. Zeitschrift für Pädagogik, 60(5), 681-695.

Kwiek, M. (2014b). Structural changes in the Polish higher education system (1990-2010): A synthetic view. European Journal of Higher Education, 4(3), 266-280.

Kwiek, M., \& Antonowicz, D. (2013). Academic work, working conditions and job satisfaction. In U. Teichler \& E. A. Höhle (Eds.), The work situation, the views and the activities of the academic profession: Findings of a questionnaire survey in twelve European countries (pp. 37-54). Dordrecht: Springer.

Kwiek, M., \& Kurkiewicz, A. (2012). The modernisation of European universities. Cross-national academic perspectives. Frankfurt/New York: Peter Lang.

Kwiek, M., \& Maassen, P. (2012). National higher education reforms in a European context: Comparative reflections on Poland and Norway. Frankfurt/New York: Peter Lang.

Maassen, P., \& Olsen, J. P. (2007). University dynamics and European integration. Dordrecht: Springer.

Maassen, P., \& Van Vught, F. A. (1996). Inside academia. New challenges for the academic profession. Enschede: CHEPS.

March, J. G., \& Olsen, J. P. (1989). Rediscovering institutions. The organizational basis of politics. New York: The Free Press.

Martin, B., \& Etzkowitz, H. (2000). The origin and evolution of the university system (SPRU electronic working paper series, 59).

Musselin, C. (2007). Transformation of academic work: Facts and analysis. In M. Kogan \& U. Teichler (Eds.), Key challenges to the academic profession (pp. 175-190). Paris/Kassel: INCHER.

Musselin, C. (2010). The market for academics. New York: Routledge.

Pinheiro, R., Benneworth, P., \& Jones, G. A. (2012). Universities and regional development: A critical assessment of tensions and contradictions. London: Routledge.

Rüegg, W. (2004). A history of the University in Europe. Vol. III. Universities in the nineteenth and early twentieth centuries (1800-1945). Cambridge: Cambridge University Press.

Schuster, J. H. (2011). The professoriate's perilous path. In J. C. Hermanowicz (Ed.), The American academic profession. Transformations in contemporary higher education (pp. 2143). Baltimore: The Johns Hopkins University Press.

Schuster, J. H., \& Finkelstein, M. J. (2006). The American faculty. The restructuring of academic work and careers. Baltimore: Johns Hopkins University Press.

Scott, P. (2003). Challenges to academic values and the organization of academic work in a time of globalization. Higher Education in Europe, XXVIII(3), 295-306.

Shattock, M. (2009). Entrepreneurialism and organizational change in higher education. In M. Shattock (Ed.), Entrepreneurialism in universities and the knowledge economy: Diversifcation and organizational change in European higher education (pp. 1-8). Berkshire: SRHE \& Open University Press.

Skolnik, M. L. (2005). Reflections on the difficulty of balancing the university's economic and non-economic objectives in periods when its economic role is highly valued. In G. A. Jones, P. L. McCarney, \& M. L. Skolnik (Eds.), Creating knowledge, strengthening nations: The changing role of higher education (pp. 106-126). Toronto: University of Toronto Press.

Teichler, U. (2007). The changing nature of higher education in Western Europe. In U. Teichler (Ed.), Higher education systems. Conceptual frameworks, comparative perspectives, empirical findings (pp. 55-68). Rotterdam: Sense.

Teichler, U., \& Yagci, Y. (2009). Changing challenges of academic work: Concepts and observations. In V. L. Meek, U. Teichler, \& M.-L. Kearney (Eds.), Higher education, research and innovation: Changing dynamics (pp. 83-146). Kassel: INCHER-Kassel.

Välimaa, J. (2008). Cultural studies in higher education research. In J. Välimaa \& O.-H. Yljoki (Eds.), Cultural perspectives on higher education (pp. 9-25). Dordrecht: Springer. 
Williams, G. (2012). Some wicked questions from the dismal science. In P. Temple (Ed.), Universities in the knowledge economy: Higher education organisation and global change (pp. 19-37). London/New York: Routledge.

Williams, G., Blackstone, T., \& Metcalf, D. (1974). The academic labour market. Economic and social aspects of a profession. Amsterdam: Elsevier.

Wilson, L. (1942/1995). The academic man. A study in the sociology of a profession. New Brunswick: Transaction Publishers.

Wilson, L. (1979). American academics. Then and now. New York: Oxford University Press.

Ziman, J. (1994). Prometheus bound. Science in a dynamic steady-state. Cambridge: Cambridge University Press.

Zuckerman, H. (1977/1996). Scientific elite. Nobel laureates in the United States. New York: Transaction Publishers. 